\title{
PRODUCT QUALITY AND PROMOTION RELATION ANALYSIS ON PURCHASING DECISION AT PT. SEJAHTERA BUANA TRADA (CASE STUDY OF SUZUKI ERTIGA)
}

\author{
Imam Yunianto \\ Informatics Engineering Department, Sekolah Tinggi Teknologi Bandung \\ imamyunianto@gmail.com
}

\begin{abstract}
This research was conducted at Car Dealer PT. Sejahtera Buana Trada Puri Indah branch with case study Suzuki Ertiga which at the time of research is selling well. In this study, researchers wanted to test whether there is a significant relationship between Product Quality with Purchase Decision. The purpose of this study knowing whether it is true that a good quality product from a car can make car sales increase, knowing whether a good promotion can increase sales and knowing if the product quality and promotion done together can increase sales. The research method use is quantitative. The sample of this research are all buyers of Suzuki Ertiga car that buy to Suzuki Sejahtera Buana Trada car dealership during the third quartet of 2013, which is between July until September 2012. Is there also a significant relationship between Promotion on Purchase Decision. As well as a significant relationship between Product Quality and Promotion together with Purchase Decision.
\end{abstract}

Keywords: Product Quality, Promotion, Purchase Decision. Suzuki Ertiga.

\section{Introduction}

For a leader in a car dealer convincing their subordinates to sell is very important, because the life of a car sales company is from how many cars sold. The more cars sold, the more advanced the automotive company. Convincing a salesman to the fact that the product being sold is a good quality product and certainly in great demand will motivate the company's spearhead to sell many products.

Nevertheless in Indonesia, cars with good quality are not much in demand. The most common example is how many European cars with qualified qualities that are less salable in Indonesia. Compared to Japanese cars which are selling well in Indonesia although the cars are not the best product of the company. There are many factors that cause Japanese cars more in demand than the European cars like the affordable price, the cost of economical maintenance and the availability of Japanese auto parts with quality that understand the income of the people in Indonesia. In addition to the above mentioned factors, there is no less important factor which is the Promotion. Because it's not a public secret, if the people of Indonesia will be willing to wait to buy a vehicle at the end of the year, because usually at the end of the year there will be many discounts for the buyers.

Factors that researchers put forward are only allegations. There has been no scientific literature given by the leadership of the company for its sales. For that the authors want to test whether the facts mentioned above can be considered scientifically responsible by 
testing the Relationship of Product Quality and Promotion of sales with Title Research Relationship Product Quality and Promotion Against Purchasing Decision in PT. Sejahtera Buana Trada (Case Study of Suzuki Ertiga).

The purpose of this research is to:

1. Knowing whether it is true that a good Quality Product from a car can make car sales increase

2. Knowing whether a good Promotion can increase sales

3. Knowing if the Product Quality and Promotion done together can increase sales

Usage of research results:

1. For Automotive Business especially Cars, this research can be one of the literature to create strategic plan in making sales strategy

2. For Academics and Students who want to make similar research, can be used as a reference.

3. For ordinary people who want to know whether the bestselling car must be good quality or a good quality car would be expensive and less desirable

\section{Theorotical Framework}

\subsection{Buying decision}

Buying decision is a real purchasing process. Where the purchasing decision process is one of the processes of the five-stage model of the Kotler consumer purchasing process and the comparison models of Engel, Kollat and Blackwell.(Swastha \& Handoko, 2013)

Purchase Decision by Kotler and Armstrong (Kotler \& Amstrong, 2012a) is Consumer buyer behavior is buying behaivor of final consumer - individuals and households who buy goods and services for personal consumption. Awater (Nugroho J Setiadi, 2003) defines decision-making is an activity of collecting information about relevant alternatives and making appropriate choices. Purchase Decision by Grifin and Ebert (Ricky W Grivin, 2012) is Buy decision-based o rational motives emotional motives, or both. Rational motives involve the logical evaluation of product attributes: cost quality and usefulness. Emotional motives involve non objective factors and include sociability, imitation of other, and aestheitics.

According to Helga Drumond (Eka Dewi Setia Tarigan SE, Putra, 2017), the meaning of Purchasing Decision is to identify all possible options for solving the problem and to assess the options systematically and objectively as well as the objectives which determine the advantages and disadvantages of each. According Setiadi (Nugroho J Setiadi, 2003), decisions taken by a person can be called a problem solving. In the process of decision-making, consumers have goals or behaviors to be achieved or satisfied. Furthermore, consumers make decisions about the behavior they want to do in order to solve the problem. Next it's explained that problem solving is a continuous reciprocal flow between environmental factors, cognitive and affective processes and behavioral actions.

The decision-making process consists of four stages. In the first stage is an understanding of the problem. The next stage will be an evaluation of available alternatives and the most appropriate action is chosen. After that the purchase is manifested in the form of action. In the end the purchased item will be used and the consumer re-evaluates the decision he or she has made. A real purchasing activity is just one stage of the whole mental process and other physical activities that occur in the purchase process at a certain time period and the fulfillment of certain needs. Other parts of the process that 
prepare and follow the real purchase are very important to understand. Analysis of a buying process is a series of steps taken by a consumer.(Swastha \& Handoko, 2013).

The stages in the process of a purchasing activity are described by Philip Kotler and the comparative models of Engel, Kollat and Blackwell as shown below. (Swastha \& Handoko, 2013). When the consumer decides to buy, the consumer will encounter a series of decisions to be made regarding the product type, product form, brand, seller, quantity, time of purchase and payment methods. (Swastha \& Handoko, 2013).

Consumers can decide to buy a car or use it for other purposes. In this case the company should focus its attention on consumers who are interested in buying a car or other alternative that they consider. Once the decision about the type of product is set, the next decision is to determine the shape of the product. The example of this type of product is three- line form car or family car, city car and sedan. Decisions on the type of product, including size, type, quality, and color.

The next decision, if the type of product and the form of the product have been decided, then the brand or the manufacturer will be selected. Sometimes there are consumers who decide to buy, just by looking at the brand of the product without being compared to the brand of similar products. Examples of brands such as Suzuki, Toyota, Daihatsu, KIA and others.

Decisions about the seller, sometimes also determine the consumer's decision whether to buy or not. In the automotive world there is a salesman named Joe Girad. To buy a car, Joe Girad's consumers willing to queue, because the service of Joe Girad is very impressive and good. About the seller also include where the dealer will be purchased. The number of products that consumers need is also important for companies to prepare units of goods in need. If unit requirements are not available, many consumers decide to cancel purchases to the company. Time of purchase by consumers, is also a factor that affects the decision to buy or not. Sometimes a decision not to buy in the near future, does not mean consumers won't buy, but will buy when they already have the money. Consumers will buy in time of need and availability of money. For that the company must ask the consumers, is the need for the product in the near future or not then when is the time. Because beside the needs, time factor is also influenced by the availability of money by consumers.

The final decision process is about how the payment is desired by the consumer. Nowadays the decision of payment method determines the consumer decision to buy or to postpone. Beside buying with cash, the company gives a convenience to buy by being financed by the leasing company, and the consumer pays the lease with installment payment. In the 16th edition of Marketing Management Manual, Volume 1, Kottler \& Keller disclose that purchasing decisions are consumer evaluations in shaping inter-brand preferences within a set of options. (Kottler \& Keller, 2016)

To purchase the most preferred brands, consumers can form five sub-decisions, those are Brand (Suzuki brand), Distributor (Suzuki Branch Sunter), Quantity (5 units of Ertiga cars), time (early November 2013) and method of payment (credit with leasing).(Kottler \& Keller, 2016). Next Amirullah (Faridatul Fitriyah, 2016) that: Decision-making is a process of appraising and selecting from alternatives according to particular interests by establishing an option that is considered most favorable. 
Decision-making has significance for the advancement of an organization, especially since the future of an organization is mostly determined by current decision-making. The importance of decision making is viewed in terms of power to make decisions, whether following the pattern of centralization or decentralization. Decision-making besides being viewed in terms of power is also seen in terms of its presence, that is without the theory of administrative decisionmaking, we can not understand, whether to forecast management actions so that we can not improve management effectiveness.

Decision-making is a process of appraising and selecting from alternatives according to particular interests by defining a choice that is considered most favorable. The assessment process usually begins by identifying key issues affecting the objectives, developing, analyzing, and selecting those alternatives and making the decisions that are considered the best. The final step of the process is the evaluation system to determine the effectiveness of the decisions taken (Machfoedz Mahmud, 2002).
In Ujang Sumarna Consumer Behavior book, Schifman and Kanuk define a decision as the selection of an action of two or more alternatives (Machfoedz Mahmud, 2002). A consumer who wants to make a choice, must have an alternative choice. A consumer who wants to buy a family car, faced with several choices of vehicle brands, such as Suzuki, Toyota, Daihatsu and Nissan. Thus the consumer must take a decision about what brand will be bought. Or the consumer should choose one and several alternative options, such as on the purchase of drugs according to a doctor's prescription, this is not the situation consumers to do the decisions. A decision without being referred to as Hobson's Choice. (Machfoedz Mahmud, 2002).

According to Engel consumer decision process is an important thing that consumers do in buying a product (Enggel, Roger DB, 1994). Consumer decision process is an important activity because in the process contains various steps that occur in sequence before the consumer takes a decision. The steps of the process are: analyzing the wants and needs, investigating external sources, alternative assessments, the actual purchase process and the post-purchase assessment as shown in Figure 2.1.

(Stages of purchasing process according to Kotler)

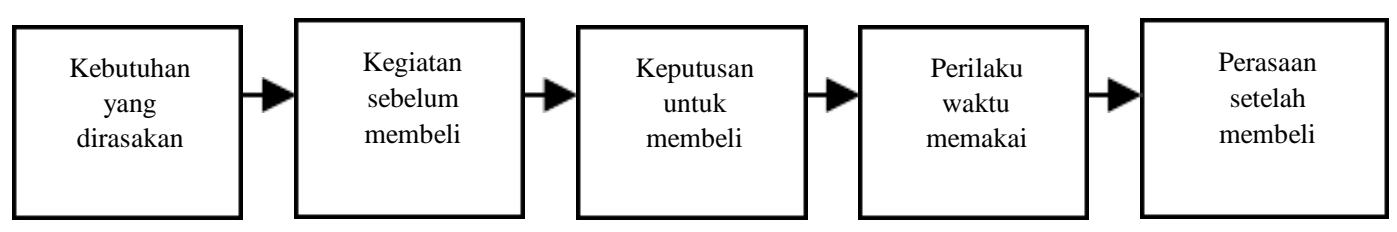

(Stages of purchasing process according to Engel, Kollat and Blackwell)

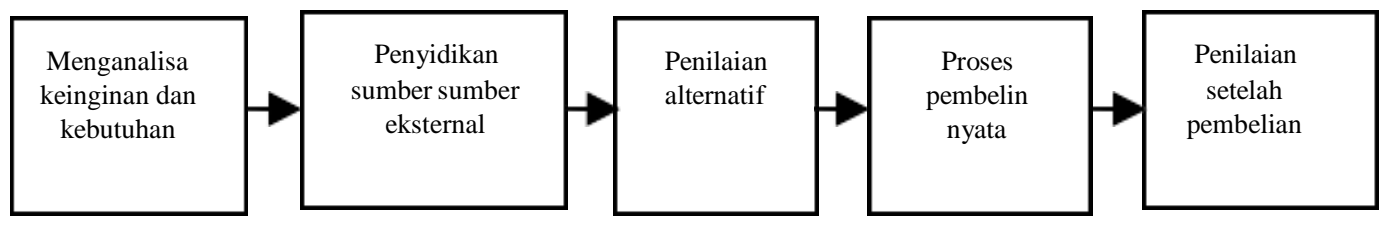

Figure 2.1 Stages in the buying process

Source: Consumer Behavior Analysis of Swastha \& Handoko 
Introduction of wants and needs, consumers trying to find out what are the needs and desires, both planned and appear suddenly. The difference or incompatibility between the desired state and the actual state, will generate and activate the needs process. Searching information and assessment of internal search sources into memory to determine possible solutions. If the solution can not be obtained through an internal search, then the search process is focused on external stimulus that are relevant in solving the problem (external search).

The info can be: personal sources, such as opinions and attitudes of friends, acquaintances, family, free sources such as consumer groups and government agencies, marketing sources such as advertisements, direct experience sources such as direct visits to stores, direct product testing. Consumers look for what can meet their needs and wants. After knowing what is right then they will do the assessment along with the considerations obtained from various information related to the length of time and the amount of money available to buy.

Assessment and selection of alternative purchases consist of two stages: establishing the purpose of purchasing and assessing and selecting alternatives based on purchasing objectives. Once the consumer gathers information about an alternative answer to a need, the consumer will evaluate the options and simplify the options on the desired alternative. Buying decision, process in buying decision, after passing the previous stages. If the consumer is satisfied from the purchase then there will be a repurchase. Consumers make real purchase based on selected alternatives.

Buying decisions include consumer's decisions about what to buy, decision to buy or not, time of purchase, place of purchase, and payment method. Behavior after the purchase. This behavior affects repeat purchase and also affects the sayings of buyers to other parties about the company's product. Based on the description above, the stage of decision-making process of buying consists of six stages, which begins with the stages of introduction of needs, then to the second stage of search information and assessment of resources, proceed to the third stage of alternative evaluation.

From the above theories based on the book Marketing Management Consumer Behavior Analysis, First Edition, by Basu Swastha Dharmmesta and Farm Handoko, the sixth printing, March 2013 page 110, it can be concluded that the purchase decision is a process in real purchasing. Where the purchasing decision process is one of the processes of the five-stage model of the Kotler consumer purchasing process and the comparison models of Engel, Kollat and Blackwel.

\subsection{Product quality}

A quality perspective is an approach used to realize the quality of a product. Garvin (Fandy Tjiptono \& Anastasia Diana, 2003) identifies five commonly used quality perspectives: Transcendental Approach, Product Based Approach, User based Approach, Manufacturing Based Approach, Value Based Approach.

Transcendental Approach. According to this approach the quality can be perceived and known, but it is difficult to define and operationalize. This point of view is usually applied in the art of music, drama, dance, and fine art. In addition, the company can promote its products with questions, such as a fun shopping place (supermarkets), elegant (cars), beauty (cosmetics), and skin softness (scrubs). Thus, the function of planning, production, and service of a company is difficult to use this 
definition as the basis of quality management. Product Based Approach. This approach regards quality as a quantifiable and measurable feature or attribute. Differences in product quality reflect differences in the number of elements or attributes that a product has. Since this view is highly objective, it can not explain the differences in individual tastes, needs and preferences.

User based Approach. This approach is based on the idea that product quality depends on the person using it and the product that satisfies one's preferences is the highest quality product. This subjective and demand oriented perspective also states that different consumers have different needs and wants. Thus, the quality of the product for a person is equal to the maximum satisfaction he perceives.

Manufacturing Based Approach. This perspective is supply-based and primarily concerned with engineering and manufacturing practices, as well as defining quality equals requirements. In the service sector it can be said that the quality can be operational driven. This approach focuses on adjusting internally developed specifications, often driven by the goal of increasing productivity and cost suppression. So that determines the quality of the product is the standards set by the company, not the consumers.

Value Based Approach. This approach sees quality in terms of value and price. Taking into account the trade off between product performance and price, quality is defined as affordable excellence. The quality of the product in this perspective is relative, so the highest quality product is not necessarily the most valuable. However, the most valuable products or services are most appropriate to buy (best buy).

Garvin (Fandy Tjiptono \& Anastasia Diana, 2003) has revealed the existence of eight dimensions of product quality that marketers can play. Performance, feature, reliability, conformance to specifications, durability, serviceability, aesthetics, and perceived quality is the eight dimensions. Dimensions performance or product performance characteristics or performance is the primary function of a product. This is the main benefits or benefits of the products we buy. Usually this is the first consideration we buy the product. Dimensional reliability or product reliability the second dimension is reliability, is the chances of a product free from failure when performing its function.

Dimensional features or product features. Dimensional feature is a characteristic or additional characteristics that complement the basic benefits of a product. Features are optional or option for consumers. If the main benefits are standard, features are often added. The idea, the feature can improve product quality if competitors don't have it. Dimensions of durability or durability Durability indicates the age of the product, it's the amount of use of a product before it is replaced or damaged. The longer the durability would be more durable. Durable products will be perceived to be better quality than fast or quickly replaced products.

Dimensions of conformance or conformity. Conformance is the conformity of product performance with the stated standard of a product. It's a kind of promise that must be fulfilled by the product. Products that have the quality of this dimension that mean the products are according to the standard. Dimensions of serviceability or ability to improve. In accordance with its meaning, here the quality of the product is determined on the basis of the ability to repair: easy, fast, and competent. Products that can be repaired surely have higher quality than the products 
that can not or difficult to repair.

The aesthetic dimensions or the beauty of Aesthetic product look or beauty concerns the appearance of the products that make consumers love. This is often done in the form of product desiccation or packaging. Some brands renew their faces to be more beautiful in the eyes of consumers.

Perceived quality dimension or perceived quality the last dimension is perceived quality. This concerns consumer ratings of imagery, brands, or advertisements. Well-known branded products are usually perceived to be more quality than the unheard brands. That is why the product always strives to build its brand so as to have a high brand equity. Of course this can not be built overnight because it involves many aspects including quality dimensions of performance, features, endurance, and so on

According to the American Society for Quality Control (Jay Heizer \& Barry Render, 2016) , quality is a product or service characteristic that depends on its ability to satisfy the stated or implied customer requirements. However, some people believe that the definition of quality is divided into three categories: user-based quality, manufacturingbased quality and product- based quality. (Jay Heizer \& Barry Render, 2016).

User-based quality is quality that depends on the audience. Higher quality means better performance, better features and other improvements. Quality-based manufacturing is a quality that is determined by making the product correctly from the beginning. Product-based quality views quality as a precise and quantifiable variable. Siemens also defines quality in this way in Kottler's book (Kotler \& Amstrong, 2012b), Quality is when our customers come back and our products do not come back.

Kottler (Kotler \& Amstrong, 2012b) states that the achievement of good quality for companies need some measure to formulate policy regarding product quality that is: function of goods, external form such as shape, color and arrangement and cost of goods. The function of goods influence consumer satisfaction, it must reproduce goods of quality in accordance with the function and its usefulness, durability, equipment and beliefs. External shape such as shape, color and stacking. If the outward form of the item is not attractive even though the quality of the goods is good then not necessarily the consumers are interested.

The cost of goods in general the cost and price of an item will be able to determine the quality of an item. Geotsch and Davis (1994) (Fandy Tjiptono \& Anastasia Diana, 2003) makes a definition of quality: Quality is a dynamic condition associated with products, services, people, processes, and environments that meet or exceed expectations. According to Gasperz (Gasperz V, 1997) Product Quality is defined as the requirements of a product to satisfy users of the product or consumer by comparing the product to the competition and to the best product on the market. Product quality is determined through product design and is achieved through effective control techniques, as well as providing satisfaction over the life of the product. Product quality can also be said to be part of every function in all stages of the product cycle. Quality of products can be guaranteed through inspection: inspection of material arrival, inspection of the resulting product, improving quality through more rigorous inspection and increasing cost.(Gasperz $\mathrm{V}$, 1997) From the above theories based on Geotsch and Davis (1994) in Fandy Tjiptono and Anastasia Diana, 2003 , it can be concluded that quality is a dynamic condition associated with 
products, services, people, processes and environments that meet or exceed expectations.

\subsection{Promotion}

Promotion is a form of marketing communication, which is a marketing activity that seeks to disseminate information, influence / persuade, and / or remind the target market of the company and its products to be willing to accept, buy and loyal to the product offered by the company concerned (Fandy Tjiptono, 2002).

Promotion is a sales promotion consisting of short- term incentives to encourage the purchase or sale of a product or service within a certain period (Suharno, 2010). Defines sales promotions consisting of a range of techniques used to achieve the selling / marketing objectives with effective cost- effectiveness, by adding value to products or services to both intermediaries and direct users, usually not restricted within a certain timeframe (Cumins Julian, 2010).

Promotion is a seller and buyer information communication that aims to change attitudes and behavior of buyers who don't know to become familiar with being a buyer and still remember the product (Djaslim Saladin, 2007). Promotion comes from the Latin word means to move forward. In marketing, promotion has the same meaning, especially to motivate or motivate consumers to act (A Shimp Terance, 2014).

Promotion is communication link between buyers and sellers, the function of informing, persuading and influencing a consumers purchase decision (Kurlz L David, 2013). Defines promotion as comunication that informs the potential customers of the existence of product, and persuade them that products have want satifiying capabilities (Buchari Alma, 2014).
Wiliam J. Stanton (1981), states that Basicly, promotion is an exercise in information, persuasion and conversely, a person who is persuaded is also being informed (Buchari Alma, 2014). Based on the opinion of Ben M. Enis and Wilian J Stanton above, Buchari Alma concluded that the promotion is a kind of communication that gives explanations that convince potential customers about goods and services (Buchari Alma, 2014).

Promotion is marketers effort to communicate with target audiences. Communications is the process of influencing others behavior by sharing ideas, information or feeling with them. Promotion is a business undertaken by the marketer, communicating with potential audiences Wiliam Schoell (1993) (Buchari Alma, 2014). Communication is a process of sharing ideas, information, or feelings of the audience. Promotion in marketing aims to inform, influence and persuade, and to remind target consumers about the company and its marketing mix.

Promotion is one element in the marketing mix that can not be ignored in a buying decision process. In an effort to support the decision to purchase a product and introduce it to other people or consumers, as well as attract consumers to buy products, it is necessary an attempt to promote the product. Promotion in addition to have benefits in introducing new products, is also very important in terms of maintaining the tastes of consumers to continue to consume products that already exist. However incessant the promotional activities undertaken by the company, need to be supported by the price and quality of promoted products, so the company's goal to achieve volume of sales turnover and market share will be achieved.

Promotion is a flow of information and 
one-way persuasion made to direct a person or organization to actions that create exchanges in marketing (Swastha \& Irawan, 2008).In this case, the company must be able to determine or select media that can be used to support successful marketing. So these activities need to be combined, coordinated so that the company can perform marketing tasks well, so that the company not only choose the best combination, but also coordinate the various elements of the marketing mix.

The notion of promotion is any form that is paid from personal statements and ideas, objects and services performed by those who pay for it (Winardi, 2015). Promotion made in an attempt to change the circumstances, tendencies and willingness to act positively or negatively (the pros and cons) of certain ideas, objects or services (Kottler \& Keller, 2016).

This it can be said that promotional activity is an effort to change the image of a consumer to a marketed product, so that consumers have the desire to buy and use products offered by the company concerned. From various theories on above and according to Buchari Alma's book, Marketing Management and Marketing Services, 2014, Revised Edition, it can be concluded that promotion is a kind of communication that gives explanations that convince potential customers about goods and services.

\section{Methodology}

\subsection{Research design}

This research uses survey method with correlation technique.

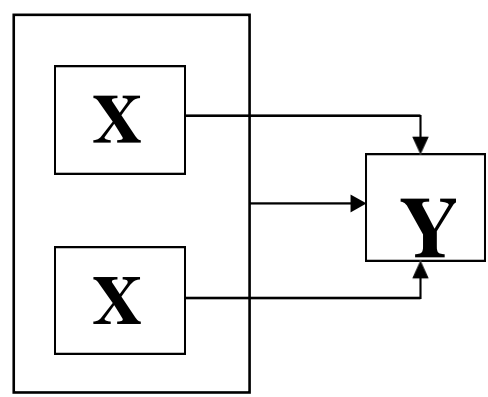

Information:

$\mathrm{Y}=$ Dependent variable: Purchase Decision

$\mathrm{X}_{1}=$ Independent variable: Product Quality

$\mathrm{X}_{2}=$ Independent variable:

\subsection{Population and Sample Population}

The target population of consumers of Suzuki Ertiga is all car consumers who have purchased Suzuki Ertiga throughout Jakarta. Affordable population of consumers Suzuki Ertiga is all consumers who come to Suzuki Sejahtera Buana Trada Dealer Puri Indah branch.

\section{Sample}

This jurnal samples are all buyers of Suzuki Ertiga car that buy to Suzuki Sejahtera Buana Trada car dealership during the third quarter of 2013, which is between July until September 2013. From the number of buyers in the third quarter of 2013 amounted to 170 units determined using Slovin formula, namely:

\section{Forms of Quantitative Research}

$$
\begin{aligned}
& \mathrm{n}=\underline{\mathrm{N}} \\
& \mathrm{n}=\text { Sample } \\
& \mathrm{N}=\text { Population } \\
& \mathrm{E}=\text { margin of error }(0.01,0.02,0.03, \\
& 0.04,0.05,0.10) \\
& \frac{170}{120 \quad=\underline{170}}=119.28= \\
& 1+\left(170 \times 0.05^{2}\right) 1.425
\end{aligned}
$$

\subsection{Data collection technique}

Technique of collecting data in this Research using a questionnaire instrument, test and study document.

\section{Result and Discusion}

\subsection{Product Quality Relation with}




\section{Purchase Decision}

The first research hypothesis formula is there is a significant relationship between Product Quality $\left(\mathrm{X}_{1}\right)$ with Purchase Decision (Y). From the results of regression analysis showed that Quality Products $\left(\mathrm{X}_{1}\right)$ with the purchase decision $(\mathrm{Y})$ is plotted against the equation $\mathrm{Y}=101.085+0.172 \mathrm{X}_{1}$, as in Figure 4.1 and Table 4.1 below. This means that the regression equation $\mathrm{Y}=$ $101.085+0.172 \mathrm{X}_{1}$ dap at used as a tool to describe and draw conclusions about the relationship of Product Quality (X 1), and Purchase Decision (Y). This equation has the following meanings: egression coefficient of 0.172 states that each increase of one unit, Product Quality, will raise 0.172 units Purchase Decision. To test the significance of constant and exogenous variables Product Quality used t test, where:

Hypothesis:

$\mathrm{H}_{0}$ : Product Quality Variables are not significantly related to the Purchase Decision variable

$\mathrm{H}_{\mathrm{a}}$ : Product Quality Variables correlate significantly to the Purchase Decision variable. Basis of decision maker:

If the probability (Sig. Value) $>0.05$ or $\mathrm{t}$ arithmetic < t table then $\mathrm{H}_{0}$ is accepted and $\mathrm{Ha}$ is rejected. If the probability (Sig. Value) $<0,05$ or $\mathrm{t}_{\text {count }}>\mathrm{t}_{\text {table }}$ then $\mathrm{H}_{0}$ is rejected and $\mathrm{H}_{\mathrm{a}}$ is accepted.

From column Sig-Product Quality_X table 4.1 obtained Sig. $=0.094$. Because Sig. $=0,094>\alpha=0,05$, then $\mathrm{H}_{0}$ is accepted, Ha is rejected.

From column t-Quality Products_X $X_{1}$ table 4.19 obtained $\mathrm{t}$ arithmetic $=$ 1.687. From the $\mathrm{t}$ distribution table (appendix 4) we obtain $\mathrm{t}_{\alpha / 2, \mathrm{n}-2}=\mathrm{t}_{0.025 \text {, }}$ $117=2.270614$.

Because $\mathrm{t}_{\text {arithmetic }}=1.687<\mathrm{t} \quad 0.025,117=$ 2.270614, then $\mathrm{H}_{0}$

accepted and Ha rejected.Because of the sig column. $\mathrm{H}_{0}$ received and from column $\mathrm{t}$ Quality of Product $\mathrm{H}_{0}$ accepted, then the conclusion Variable Product Quality is not significantly related to the variable Purchase Decisi

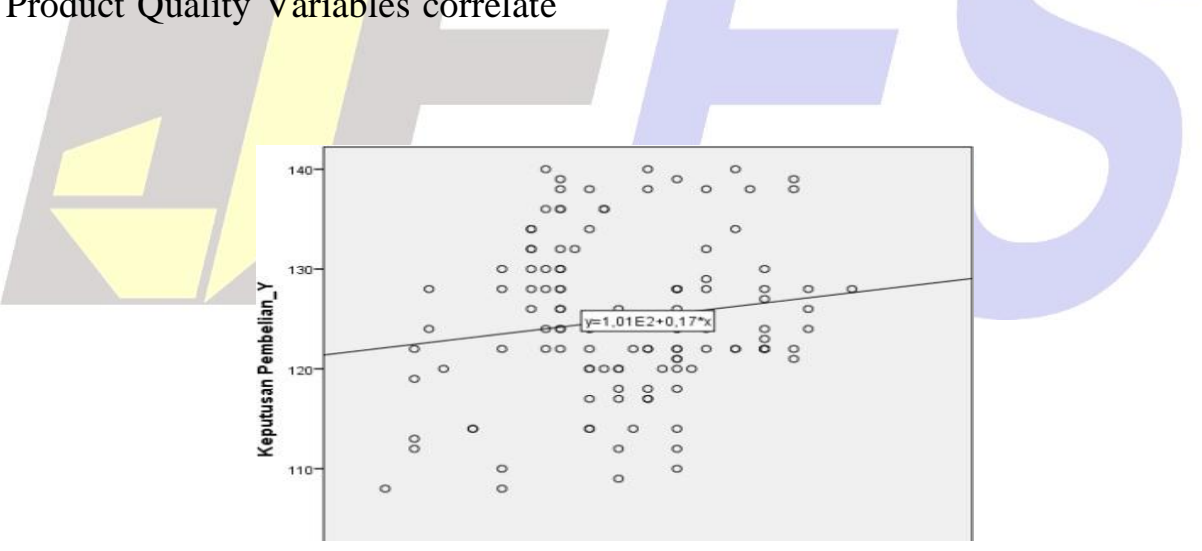

Figure 4.1 Regression Equation $Y=101.085+0.172 X 1$

Kualitas Produk_X1

Table 4.2 Correlation $\mathrm{X}_{1}$ with $\mathrm{Y}$ 


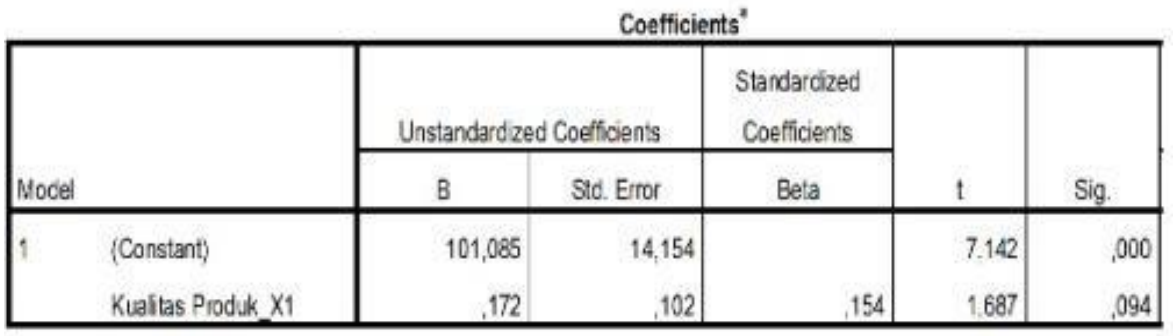

a. Dependert Variable: Keputusan Pembelian_Y

Furthermore, from table 4.2 used to know the significancy level of regression. If the regression is not significant it indicates that there is no linear relationship between
$\mathrm{X}_{1}$ with $\mathrm{Y}$ or in other words a simple linear regression model (RLS) is not suitable for predicting Y.

Table 4.3 Correlation X 1 with Y Correlations

\begin{tabular}{|ll|r|r|}
\hline & & $\begin{array}{l}\text { Purchase } \\
\text { Decision_Y }\end{array}$ & $\begin{array}{l}\text { Product } \\
\text { Quality_X1 }\end{array}$ \\
\hline $\begin{array}{l}\text { Pearson } \\
\text { Correlation }\end{array}$ & Purchase Decision_Y & 1,000 &, 154 \\
\hline & Product Quality_X1 &, 154 & 1,000 \\
\hline Sig. (1-tailed) & Purchase Decision_Y &. &, 047 \\
& Product Quality_X1 &, 047 & \\
\hline $\mathrm{N}$ & Purchase Decision_Y & 119 & 119 \\
& Product Quality_X1 & 119 & 119 \\
\hline & & & \\
\hline
\end{tabular}

Table 4.3 gives information about the value of correlation between $X_{1}$ Product Quality and Y (Purchase Decision). To be able to use Tab el 4.2 hypothesis test. $\mathrm{H}_{0}: \beta=0$ (no correlation of Product Quality and Purchase Decision)

$\mathrm{H}_{\mathrm{a}}: \beta>0$ (there is a positive correlation between Product Quality and Purchase Decision) From Table 4.2 Column of Product Quality obtained correlation pearson $r=0,154$.

From common Sig. (1-tailed) table 4.2 obtained Sig. (1-tailed) $=0.47$. Because Sig. $(1$-tailed $)=0.47>\alpha=0,05$, then $\mathrm{H}_{0}$ is accepted and $\mathrm{Ha}$ is rejected. In other words, there is no significant correlation between Product Quality and Purchase Decision.

$\mathrm{H}_{0}: \beta=0$ (no correlation of Product Quality and Purchase Decision)

$\mathrm{H}_{\mathrm{a}}: \beta>0$ (there is a positive correlation between Product Quality and Purchase Decision)
From Table 4.2 Column of Product Quality obtained correlation Pearson $\mathrm{r}=$ 0,154. From komom Sig. (1-tailed) table 4.2 obtained Sig. (1-tailed) $=0.47$. Because Sig. (1-tailed) $=0.47>\alpha=$ 0,05 , then $\mathrm{H}_{0}$ is accepted and $\mathrm{H}_{\mathrm{a}}$ is rejected. In other words, there is no significant correlation between Product Quality and Purchase Decision.

\subsection{Promotion Relations with Purchasing Section}

The second research hypothesis formula is there is a significant relationship between Promotion $\left(\mathrm{X}_{2}\right)$ with Purchase Decision (Y).

From result of regression analysis, it is found that Promotion $\left(\mathrm{X}_{2}\right)$ with Purchase Decision (Y) is described as ap equation $\dot{\mathrm{Y}}=64,47+1,119 \mathrm{X}_{2}$, seperti in figure 4. 2 and table 4. 3 below. This means that the regression equation $\dot{Y}=64.47+1.119 \mathrm{X}_{2}$ can be used as a tool for explaining and 
drawing conclusions about Promotion relationship $\left(\mathrm{X}_{2}\right)$ and Decision Pembelian (Y). This equation has the meaning as follows:

The regression coefficient of 1.119, states that each increase of one Promotion unit, will raise 1.119 units Purchase Decision to the constant 64.47.

For test of significance of constant and exogenous variable of Promotion used test, where: Hypothesis:

$\mathrm{H}_{0}$ : Promotion variable is not significantly related to Purchase Decision variable

$\mathrm{H}_{\mathrm{a}}$ : Promotion variable is significantly related to Purchase Decision variable Basis of decision maker:

For test of significance of constant and exogenous variable of Promotion used $t$ test, where: Hypothesis:

$\mathrm{H}_{0}$ : Promotion variable is not significantly related to Purchase Decision variable

$\mathrm{H}_{\mathrm{a}}$ : Promotion variable is significantly related to Purchase Decision variable

Purchase Decision variable

Basis of decision maker:

If the probability (Sig. Value) $>0.05$ or $t$ arithmetic $<\mathrm{t}_{\text {table }}$ then $\mathrm{H}_{0}$ is accepted and $\mathrm{H}_{\mathrm{a}}$ is rejected.

If the probability (Sig. Value) $<0,05$ or $\mathrm{t}$ count $>\mathrm{t}_{\text {table }}$ then $\mathrm{H}_{0}$ is rejected and $\mathrm{H}_{\mathrm{a}}$ is accepted.

From column Sig - Promosi_X $X_{2}$, table 4. 3 obtained Sig. $=0,000$. Because the value of Sig. $=0,000<\alpha=0.05$, then $\mathrm{H}_{0}$ is rejected and $\mathrm{H}_{\mathrm{a}}$ is accepted.

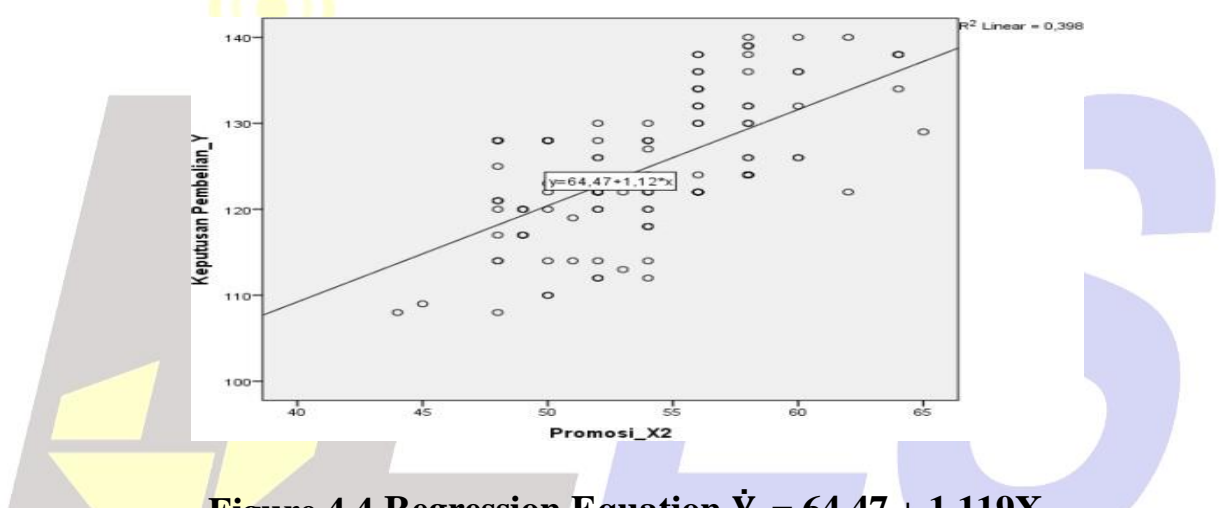

Figure 4.4 Regression Equation $\dot{Y}=64,47+1,119 X_{2}$

From column t-Promosi_ $\mathrm{X}_{2}$, table 4.4 obtained $t_{\text {count }}=8,787$. From the $T$ distribution table (appendix 3) we obtain $\mathrm{t}_{\alpha / 2, \mathrm{n}-2}=\mathrm{t}_{0,025,117}=2,270614$. Because tcount $=8.787>\mathrm{t}_{0.025,117}=2.270614$, then $\mathrm{H}_{0}$ is rejected and $\mathrm{H}_{\mathrm{a}}$ accepted.
Because of the Sig column. $\mathrm{H}_{\mathrm{a}}$ received and from the column $t$ Promotion $\mathrm{H}_{\mathrm{a}}$ also accepted, then the conclusion Promotional Variables correlated significantly to the variable Purchase Decision.

Table 4.5 Correlation $\mathrm{X}_{2}$ with Y Correlations

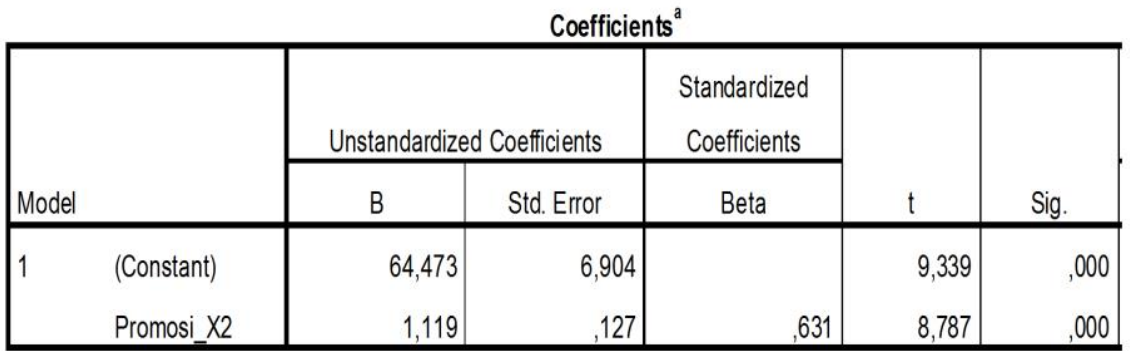

a. Dependent Variable: Keputusan Pembelian_Y 
The correlation strength between Promotion Variables with Purchase Decision

Variables is shown on the calculation of correlation coefficient of Product Moment correlation formula $\left(\mathrm{r}_{\mathrm{X} 2, \mathrm{Y}}\right)$ is
0.631. According to table 4.5 Correlation Coefficient Criteria, Correlation between Promotion Variables $\left(\mathrm{X}_{2}\right)$ with Variables Decision Purchase (Y) is Medium Correlation (Moderate).

Table 4. 6 Correlation Coefficient Criteria

\begin{tabular}{|l|l|l|}
\hline POSITIVE & NEGATIVE & INTERPRETATION \\
\hline $0.90-1.00$ & $-0.90--1.00$ & The correlation is very high \\
\hline $0.70-0.90$ & $-0.70--0.90$ & High correlation \\
\hline $0.50-0.70$ & $-0.50--0.70$ & Medium correlation \\
\hline $0.30-0.50$ & $-0.30--0.50$ & Low correlation \\
\hline $0.00-0.30$ & $-0.00--0.30$ & Small correlation \\
\hline
\end{tabular}

Table 4.6 gives information about the value of correlation between $\mathrm{X}_{2}$ Promotion and Y (Purchase Decision). To use Table 4. 5 hypothesis test is done:

$\mathrm{H}_{0}: \beta=0$ (no correlation of Promotion and Purchase Decision)

$\mathrm{H}_{\mathrm{a}}: \beta>0$ (there is a positive correlation between Promotion and Purchase Decision)

Dari tabel 4.2 kolom Kualitas Produk diperoleh korelasi pearson $r=0,154$.

From the Sig column. (1-tailed ) table 4. 5 obtained Sig. (1-tailed) $=0,000$. Because Sig. $(1$-tailed $)=0.00<\alpha=0.05$, then $\mathrm{H}_{0}$ is rejected and $\mathrm{H}_{\mathrm{a}}$ accepted. In other words, there is a positive correlation between Promotion and Purchase Decision.

From these results it is concluded that there is a positive correlation between Promotion and Purchase Decision

Tabel 4.7

Korelasi X2 dengan Y

\begin{tabular}{|c|c|c|c|}
\hline & & $\begin{array}{l}\text { Purchase } \\
\text { Decision_Y }\end{array}$ & Promotion_X2 \\
\hline \multirow[t]{2}{*}{$\begin{array}{l}\text { Pearson } \\
\text { Correlation }\end{array}$} & $\begin{array}{l}\text { Purchase } \\
\text { Decision_Y }\end{array}$ & 1,000 &, 631 \\
\hline & Promotion_X2 &, 631 & 1,000 \\
\hline Sig. (1-tailed) & $\begin{array}{l}\text { Purchase } \\
\text { Decision_Y } \\
\text { Promotion_X2 }\end{array}$ &, 000 &, 000 \\
\hline $\mathrm{N}$ & $\begin{array}{l}\text { Purchase } \\
\text { Decision_Y } \\
\text { Promotion_X2 }\end{array}$ & $\begin{array}{l}119 \\
119\end{array}$ & $\begin{array}{l}119 \\
119\end{array}$ \\
\hline
\end{tabular}

Table 4. 8

\begin{tabular}{|l|l|l|l|l|}
\hline Model & $\mathrm{R}$ & $\mathrm{R}$ Square & Adjusted R Square & $\begin{array}{l}\text { Std. } \\
\text { Error of the Estimate }\end{array}$ \\
\hline
\end{tabular}




\begin{tabular}{|l|l|l|r|r|}
\hline 1 &, $631 \mathrm{a}$ &, 398 &, 392 & 6,128 \\
\hline
\end{tabular}

Tabel 4. 8 provides information on several things, namely:

Column R Square or $\mathrm{R}^{2}$ is the coefficient of determination. Column $\mathrm{R}$ Square means that R $2=0.631$ or $63.1 \%$ of the variation of $\mathrm{Y}$ (Decision Purchase) can be explained by $\mathrm{X}_{2}$ (Promotion). Can also be shown that if the value of $r$ in RLS also called the coefficient ko relation modest in Table 4. 6 squared will produce $\mathrm{R}^{2}$ or $\mathrm{R}^{2}=0.631=0.398$. Adjusted R Square column is the value of $\mathrm{R}^{2}$ (fixed), that is equal to 0.392 .

Std Column. Error of the Estimates are the estimated standard error that indicates the size of variabillitas between $\mathrm{X}_{2}$ with $\mathrm{Y}$ predictions. From Table 4.6 earned an estimated standard error of 6.128. Because Std Error of the Estimates $=6.128<$ from Std Deviation $\mathrm{Y}=7,862$, then the predictor used as independent variable is declared feasible.

\subsection{Relationship of Product Quality and Promotion with Purchase} Decision
The third formulation of the research hypothesis is that there is a significant relationship between Product Quality $\left(\mathrm{X}_{1}\right)$ and Promotion $\left(\mathrm{X}_{2}\right)$ together with Purchase Decision (Y).

From the results of the regression analysis in Table 4. 3 shows that the Product Quality $\left(\mathrm{X}_{1}\right)$ and Promotion $\left(\mathrm{X}_{2}\right)$ the Purchase Decision $(\mathrm{Y})$ is plotted against the equation $\mathrm{Y}=$ $49.402+0.115 \mathrm{X}_{1}+1.104 \mathrm{X}_{2}$. Where the equation $\dot{Y}=49.402+$ $0.115 \mathrm{X}_{1}+1,104 \mathrm{X}_{2}$ is also shown by figure 4.3 . This means that the regression equation $\dot{Y}=49.402+$ $0.115 \mathrm{X}_{1}+1,104 \mathrm{X}_{2}$ has the following meanings:

Regression coefficient of 0.115 , noting that every increase of one unit of Product Quality, will raise unit Purchase Decision by 0,115 to constant 49,402

The regression coefficient of 1.104, states that every increase of one Promotion unit, will raise 1.104 units of Purchase Decision to the constant 49.402 .

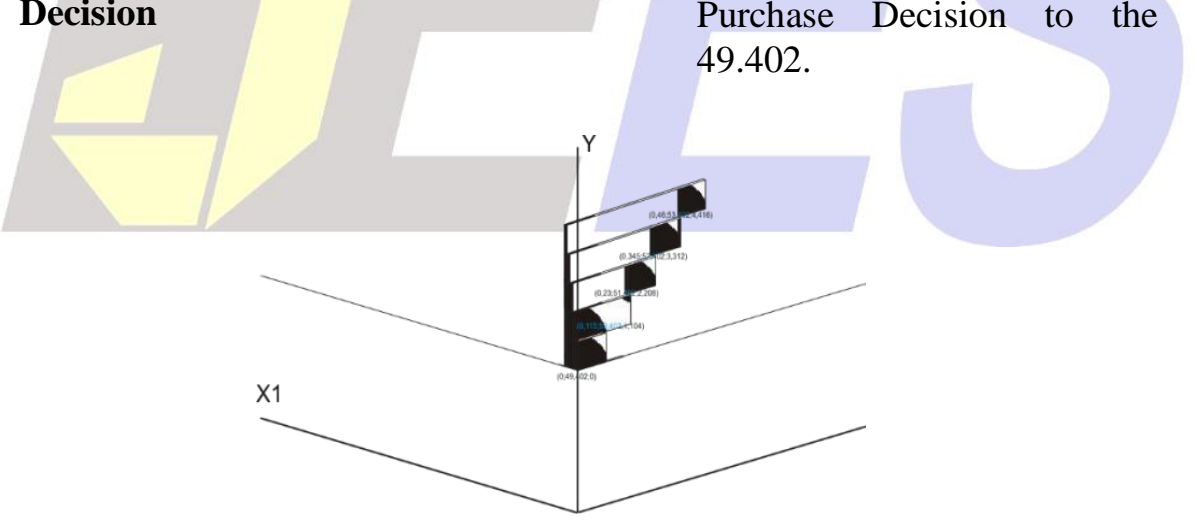

Figure 4. 3 Regression Equation $\dot{Y}=49,402+0115 X_{1}+1,104 X_{2}$

Table. 4.9

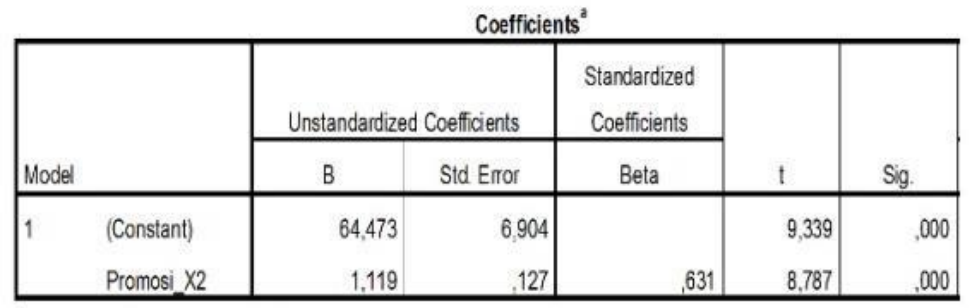

a. Dependent Variable: Keputusan Pembelian Y 
Promotion $\mathrm{X}_{2}$ with $\mathrm{Y}$ (Purchase Decision) partially. can use Table 4. 8 hypothesis test; Hypothesis:

$\mathrm{H} 0: \beta=0$ (no correlation)

Ha: $\beta \neq 0$ (no correlation)

Level of significance $\alpha=5 \%=0.005$

Row $\mathrm{X}_{1}$ obtained Pearson Correlation $=$ 0,154 . Of the value of $r\left(X_{1}\right)=0.154$

indicates that the product quality is not significantly correlated with Decision Pe $\mathrm{m}$ purchase. From table 4. 8 also obtained Sig. (2.tailed) $\mathrm{X}_{1}=0.94$. Since the level of significance is $0.94>\alpha=$ 0.05 , then $\mathrm{H}_{\mathrm{o}}$ is accepted and $\mathrm{H}_{\mathrm{a}}$ is rejected. So Product Quality is not correlated with Purchase Decision.

Row $\mathrm{X}_{2}$ is obtained Pearson Correlation $=0,631$, sign $* *$ indicates that $\mathrm{H}_{0}$ is rejected and $\mathrm{H}_{\mathrm{a}}$ accepted. The larger $\mathrm{r}$ also indicates a large correlation. From the value of $r\left(X_{2}\right)=0,631$ indicates that Promotion $\left(\mathrm{X}_{2}\right)$ has correlation with Purchase Section (Y). From table 4. 8 obtained Sig, (2.tailed) $\mathrm{X}_{2}=0,000$. Since the significance level is $0,000<\alpha$ $=0.005$, then $\mathrm{H}_{0}$ is rejected and $\mathrm{Ha}$ is accepted. So Promotion has significant correlation with purchasing decision at $5 \%$ significance level and also significant at $1 \%$.

To test the correlation of Product Quality and Promotion together with Decision Purchase, Hypothesis:

$\mathrm{H}_{0}=\beta_{1}=\beta_{2}$

$\mathrm{H}_{\mathrm{a}}=$ at least one where $\beta_{\mathrm{k}} \neq 0$.

Double Correlation Hypothesis Test: $F_{h}<F_{t}=$ Correlation is not significant $F_{h}>F_{t}=$ Correction is significant use

Table. 4.10 Correlations

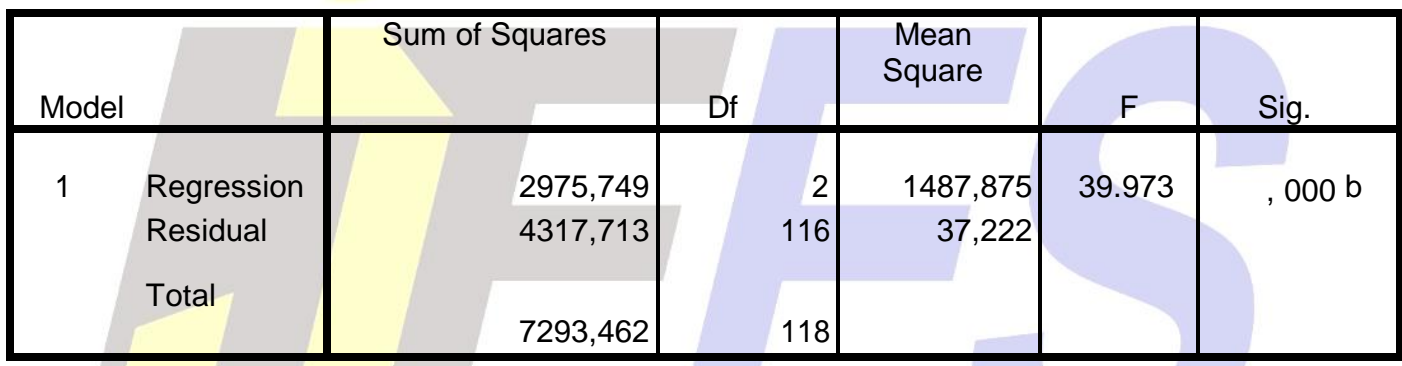

Table 4.10 provides information on the value of correlation between Product Quality $\mathrm{X}_{1}$ and Promotion $\mathrm{X}_{2}$ with $\mathrm{Y}$ (Purchase Decision) partially. Un tuk can use Table 4.8 hypothesis test;

Hypothesis:

$\mathrm{H}_{0}: \beta=0$ (no correlation)

$\mathrm{H}_{\mathrm{a}}: \beta \neq 0$ (no correlation)

Level of significance $\alpha=5 \%=0.005$

Row $\mathrm{X}_{1}$ obtained Pearson Correlation $=$ 0,154 . Of the value of $r\left(X_{1}\right)=0.154$ indicates that the product quality is not significantly correlated with Decision purchase. From table 4. 8 also obtained Sig. (2.tailed) $\mathrm{X}_{1}=0.94$. Since the level of significance is $0.94>\alpha=0.05$, then $\mathrm{H}_{\mathrm{o}}$ is accepted and $\mathrm{H}_{\mathrm{a}}$ is rejected. So Product Quality is not correlated with Purchase Decision.

Row $\mathrm{X}_{2}$ is obtained Pearson Correlation
$=0,631, \operatorname{sign} * *$ indicates that $\mathrm{H}_{0}$ is rejected and $\mathrm{Ha}$ accepted. The larger $\mathrm{r}$ also indicates a large correlation. From the value of $\mathrm{r}\left(\mathrm{X}_{2}\right)=0,631$ indicates that Promotion $\left(\mathrm{X}_{2}\right)$ has correlation with Purchase Section (Y). From table 4. 8 obtained Sig, (2.tailed) $\mathrm{X}_{2}=0,000$. Since the significance level is $0,000<\alpha$ $=0.005$, then $\mathrm{H}_{0}$ is rejected and $\mathrm{H}_{\mathrm{a}}$ is accepted. So Promotion has significant correlation with purchasing decision at $5 \%$ significance level and also significant at $1 \%$.

To test the correlation of Product Quality and Promotion together with Keputusan Purchase, use Table 4. 9 . to be able to use table 4.9 hypothesis test. Hypothesis:

$\mathrm{H}_{0}=\beta_{1}=\beta_{2}$

$\mathrm{H}_{\mathrm{a}}=$ at least one where $\beta_{\mathrm{k}} \neq 0$. 
Double Correlation Hypothesis Test:

$F_{h}>F_{t}=$ Correction is significant

$\mathrm{F}_{\mathrm{h}}<\mathrm{F}_{\mathrm{t}}=$ Correlation is not significant

Table 4.11

\begin{tabular}{|l|r|r|r|r|r|}
\hline Sum of Squares & Mean Square & & \\
\hline Redel & & Df & & F & Sig. \\
\hline Residual & 2975,749 & 2 & 1487,875 & 39.973 &, $000 \mathrm{~b}$ \\
Total & 4317,713 & 116 & 37,222 & & \\
\hline
\end{tabular}

In column $\mathrm{F}$ table 4.11 obtained $\mathrm{F}_{\text {count }}=$ 39,973 and $F$ distribution table (Appendix 3) obtained $\mathrm{F}_{0,05 ; 2,116}=3,07$. Because $\mathrm{F}$ arithmetic $=39.973 \mathrm{>}$ from $\mathrm{F}_{0.05} ; \quad 2,116=3.07$, then significant correlation means $\mathrm{H}_{0}$ rejected and $\mathrm{H}_{\mathrm{a}}$ accepted.

In the Sig column. Table 4.10 obtained Sig. $=0,000$. Because Sig. $=0,000<\alpha$ $=0.005$, then $\mathrm{H}_{0}$ is rejected and $\mathrm{H}_{\mathrm{a}}$ is accepted.

The conclusion of two hypothesis test, that is by partial and by way of together there are different result which, if tested partially correlation of Product Quality $\left(\mathrm{X}_{1}\right)$ with Purchasing Decision $(\mathrm{Y})$ is not significant, but if Product Quality relation $\left(\mathrm{X}_{1}\right)$ jointly test Promotion $\left(\mathrm{X}_{2}\right)$ with Purchase Decision (Y), the result is significant.

A significant cause correlation between Quality Products $\left(\mathrm{X}_{1}\right)$ with the purchase decision (Y), if together with the Promotion $\left(\mathrm{X}_{2}\right)$ is possible because of the magnitude of the regression coefficient Promotion $\left(\mathrm{X}_{2}\right)$ of 1.104 for every unit increase in the purchase decision (Y), compared with a regression correlation $\left(\mathrm{X}_{1}\right)$ of only 0.115 units for each unit of the Purchase Decision (Y) increase.

Table 4.12 Model Summary

\begin{tabular}{|l|r|r|r|l|}
\hline Model & $\mathrm{R}$ & $\begin{array}{c}\mathrm{R} \\
\text { Square }\end{array}$ & Adjusted R Square & $\begin{array}{l}\text { Std. Error of the } \\
\text { Estimate }\end{array}$ \\
\hline 1 &, 639 &, 408 &, 398 & \\
\hline
\end{tabular}

One indicator of goodness model $\dot{\mathrm{Y}}=$ $49,402+0,115 \mathrm{X}_{1}+1,104 \mathrm{X}_{2}$ can be seen from coefficient determination $\mathrm{R}^{2}$ and $\mathrm{R}^{2}$ adjusted asin table $4: 31$.

From table 4. 10 coefficient of determination, $\mathrm{R}^{2}=0.639$ or $63.9 \%$ of the average purchase decision can be explained by the variable quality and Promotional Products. The remaining
$36.1 \%$ is explained by other variables that are not taken into account in the model $\dot{\mathrm{Y}}=49.402+0.115 \mathrm{X}_{1}+1,104$ $\mathrm{X}_{2}$.

From table 4. 10 also obtained the improved coefficient of determination, $\mathrm{R}^{2}$ adjusted $=0.398$. Similarly, the $\mathrm{R}^{2}$, the size of the $\mathrm{R}^{2}$ adjusted also shows the variation of $\mathrm{Y}$ explained by the 
independent variable. Thus $39,8 \%$ of the variation of $\mathrm{Y}$ can be explained by $\mathrm{X}_{1}$ and $\mathrm{X}_{2}$, while the remaining $60.2 \%$ described other variables not been considered in the model $\mathrm{Y}=49.402+$ $0.115 \mathrm{X}_{1}+1.104 \mathrm{X}_{2}$. Differences in the use of $\mathrm{R}^{2}$ and $\mathrm{R}^{2}$ adjusted is the addition of independent variables (although independent variables are insignificant) will result in an increase in $\mathrm{R}^{2}$ while in $\mathrm{R}^{2}$ adjusted more powerful.

Estimate standard error of estimate, $\mathrm{Se}$ is a measure of the variation between $\mathrm{Y}$ and its predictive value. From table 4.31 obtained $S_{e}=6,001$. Since $S_{e}=6,001$ $<$ from Std Deviation $Y=7,862$, then the predictor used for the free variable is feasible

\section{Conclusions}

From result of research that:

Purchasing decisions from a person to vote are not affected from good product quality. Purchasing decisions from a person to choose are affected by a good Promotion. Promotion is very influential in a person to choose. This is evidenced by Good Products which will influence people to choose, if accompanied by Promotion.

Good Quality Goods should be an interest to many people. This can happen if Product Quality information goes to the public. Promotion does require a lot of money, but still must be done so that the product can be sold

\section{References}

A Shimp Terance. (2014). Periklanan Promosi \& Aspek Tambahan Komunikasi Pemasaran Terpadu (Eight). Bandung: Salemba Empat.

Amirullah. (2002). Perilaku Konsumen (First). Yogyakarta: Graha Ilmu.

Buchari Alma. (2014). Manajemen Pemasaran dan Pemasaran Jasa (Edition Re). Bandung: Alfabeta.
Cumins Julian. (2010). Sales Promotion. Tangerang: Bina Rupa Aksara.

Djaslim Saladin. (2007). Marketing Management. Bandung: PT. Linda Karya.

Eka Dewi Setia Tarigan SE, Putra, E. (2017). Pengaruh Kemasan dan Harga terhadap Keputusan Pembelian MIE SEDAAP (Studi Kasus Kelurahan CINTA DAMAI MEDAN HELVETIA), vol 3(1), 57-66.

Enggel, Roger DB, P. W. M. (1994). Consumer Behavior. Jakarta: Literatur Aksara.

Fandy Tjiptono. (2002). Manajemen Jasa (2nd ed.). Yogyakarta: Andi Offset.

Fandy Tjiptono \& Anastasia Diana. (2003). Total Quality Manajemen (Revised Ed). Yogyakarta: Andi.

Faridatul Fitriyah. (2016). Pengaruh Pendapatan, Dana Talangan Haji dan Religuitas Terhadap Keputusan Nasabah Mendaftar Haji. Jurnal Nusamba, 1(1), 5867. Retrieved from https://www.google.co.id/url?sa=t \&rct $=\mathrm{j} \& \mathrm{q}=\&$ esrc $=\mathrm{s} \&$ source $=\mathrm{web}$ $\& \mathrm{~cd}=13 \& \mathrm{cad}=\mathrm{rja} \&$ uact $=8 \& \mathrm{ved}=$ 0ahUKEwiWq5b56uzWAhWJUZ QKHdN5CV04ChAWCDEwAg \&url=http $\% 3 \mathrm{~A} \% 2 \mathrm{~F} \% 2 \mathrm{Fojs}$.unpke diri.ac.id\%2Findex.php\%2Fmanaj emen $\% 2$ Farticle $\% 2$ Fdownload $\% 2$ $\mathrm{F} 450 \% 2 \mathrm{~F} 358 \% 2 \mathrm{~F} \&$ usg $=\mathrm{AOvVa}$ w3y57Ye6ep5eW32ytli

Gasperz V. (1997). Manajemen Kualitas Dalam Industri Jasa. Jakarta: Gramedia Pustaka Utama.

Jay Heizer \& Barry Render. (2016). Operation Management (11th ed.). Jakarta: Salemba Empat.

Kotler \& Amstrong. (2012a). Principles of Marketing. New Jersey: Prentice.

Kotler \& Amstrong. (2012b). Principles of Marketing. New Jersey: Prentice Hall.

Kottler \& Keller. (2016). Marketing Management. Prananda Media.

Kurlz L David. (2013). Principle of Contempory Marketing (5 th). 
Lenggange Learning India.

Machfoedz Mahmud. (2002).

Introduction to Modern

Marketing. Yogyakarta: UPP AMP YKPN.

Nugroho J Setiadi. (2003). Consumer Behavior : Concept and Implications for Marketing Strategy and Research. Jakarta: Prananda Media.

Ricky W Grivin, R. J. E. (2012). Business Esentials. Pearson Custom Publishing.
Suharno. (2010). Marketing in Practice (First). Yogyakarta: Graha Ilmu.

Swastha \& Handoko. (2013). Marketing Management : Consumer Behavior Analysis (First). Yogyakarta: BPFE.

Swastha \& Irawan. (2008). Modern Marketing Management (Edisi 2). Yogyakarta: Liberty P.

Winardi. (2015). Enterpreneur and Enterpreneurship (cetakan ke). Jakarta: CV. Kencana.

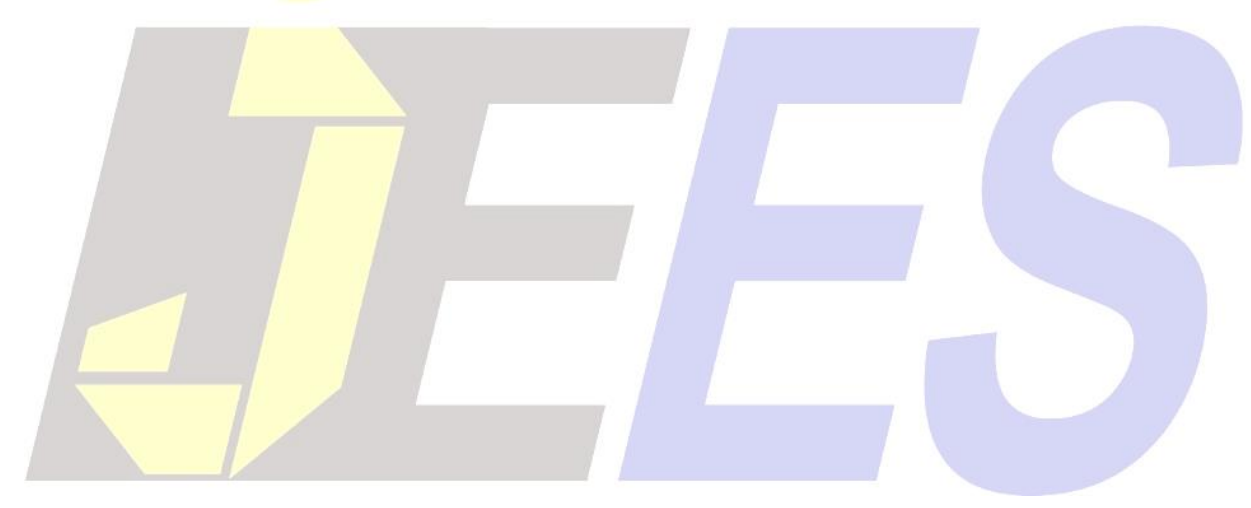

